\title{
Composition of the polypore communities of four forest areas in southern Central Finland
}

\author{
HEIKKI KOTIRANTA and TUOMO NIEMELÄ
}

\begin{abstract}
KOTIRANTA, H. \& NIEMELÄ, T. 1981: Composition of the polypore communities of four forest areas in sothern Central Finland. - Karstenia 21:31-48

The total polypore flora was studied in four nearby forest areas in southern Central Finland (province Etelä-Häme), including the Edessalo nature reserve, and the Vesijako National Park, which is one of the oldest and densest virgin spruce forests in Finland. The field work was done in the years 1978-1980, when 855 specimens were collected and about 720 sight records were made. In all, 97 species were found.

The ecology of most of the species is discussed, and their abundance and the host tree species are presented. Species reported as new to Finland are Antrodia salicina (Bres.) Niemelä, Onnia triquetra (Lenz) Imaz., Rigidoporus vitreus (Fr.) Donk, Strangulidium rennyi (Berk. \& Br.) Pouz., Tyromyces lowei (Pil.) Dom. and T. undosus (Peck) Murr. The total distribution of some rare species in Finland is given, and the concept of the so-called 'taiga element' is discussed. Preliminary observations are presented on the existence of some fungal communities e.g., the co-occurrence of Amylocystis lapponica (Rom.) Sing., Fomitopsis rosea (Fr.) Karst., Phellinus ferrugineofuscus (Karst.) Bourd. and Phlebia centrifuga Karst. on fallen trunks of Picea abies (L.) Karsten. The susceptibility of different tree species to wood-rotting polypores is discussed, and problems in the taxonomy of some rare species are briefly reviewed.
\end{abstract}

Heikki Kotiranta \& Tuomo Niemelä, Department of Botany, University of Helsinki, Unioninkatu 44, SF - 00170 Helsinki 17, Finland.

\section{Introduction}

The polyporological studies undertaken in northern Europe have mainly been devoted to single species or species groups, dealing with such subjects as their pathology, taxonomy, distribution and identification. Only seldom has attention been paid to polypore associations, and variations in the frequency of different species in certain small forest areas or forest site types. The few studies existing in this field do not allow any detailed regional surveys of the relative abundance of the species, though regional variation does, of course, occur. In fact striking differences are found if the extreme northern and southern parts of the Nordic countries are compared. The complex, gradual change in the species balance along the south-north axis is an interesting aspect of the ecology of the polypores, but one whose study is difficult and must be based on numerous accurate local investigations.

In the areas adjoining Finland, the most extensive studies have been made in Sweden (Romell 1911, Eriksson 1958, Strid 1975). The species of Finnmark, northern Norway, have been listed by Ryvarden (1971), and the study of Subin and Krutov (1979) from the ad- jacent part of the U.S.S.R. also deserves mention.

In Finland the local lists of species are chiefly from the southernmost parts. The most extensive was made by Thesleff (1919), but his study concerned the fungi of the Vyborg region, now belonging to the Soviet Union. Laine's (1967) list of the polypores of the Aland (Ahvenanmaa) archipelago gives very little information beyond the names of the species found, and the same can be said about the study of Koskinen (1955), which treated roughly the same area as the present paper. Important, annotated lists were made by Eriksson and Strid (1969) in some northern Finnish national parks and other old spruce forests. The scattered notes found in a fair number of papers (e.g., Karsten 1859, Stenlid 1947, Schulmann 1955, 1960, 1963, Kallio 1963, Kallio \& Kankainen 1966, Norokorpi 1979, Ulvinen et al. 1981) are of little help for the present study, mainly because the common species are often overlooked in them, attention being concentrated on the species which are rare in Finland. At present, an analysis of the kind made by Darimont (1973) in Belgium is beyond our reach.

Finland itself, however, is a rather good country in which to study gradual changes in the polypore species composition. All parts of it are rich in forests 
which, though seldom virgin, are made up of native tree species, and even native provenances, and have largely retained their original character. In this respect the situation is much better than in, for instance, Central Europe. The network of national parks and smaller protected reserves, though far from complete, offers a more or less sufficient series of study areas. These old forests with decaying tree trunks left lying on the ground are indispensable for this kind of study. The zonal vegetation ranges from the hemiboreal coastal strip characterized by hard-wood forest in the southernmost part of the country to the northern boreal zone in Lapland, almost reaching the northern lowland forest limit (Ahti et al. 1968). Due to the flat topography, the distributions are not much disturbed by mountain ranges.

Today, almost 170 polypore species are known to occur in Finland. Except for a handful of southern and a few strictly northern species, most of them occur in the whole of the country, but they are often more common in the south or the north. It is to be expected that many of these widespread species will show some kind of variation within their range, concerning, for instance, their biotope requirements or their host preferences.

The purpose of this paper is to offer some information on these questions. The research areas were chiefly selected in southern Central Finland because this is an interesting transitional region, harbouring species with both southern and northern distributions. The four study areas represent rather different types of forests, thus allowing comparisons between different biotopes. During the field work, special attention was paid to pathogens of living trees, because of their economic interest.

All the field work, the working up of the material, the mapping, and most of the writing were done by the author Kotiranta. The author Niemelä identified or confirmed all the collections from 1978 and the critical material collected in the later years, and wrote the taxonomical notes. The paper was finished by the two authors together.

\section{Materials and methods}

\section{Field documentation}

The field work was done in 1978-1980; in 1980 only the Vesijako National Park was studied. In 1978 altogether 19 days were spent in the study areas, in 197921 days and 1980 6 days. The specimens collected numbered 855 , and, in addition, 721 sight records were made of the common and easily identifiable species, such as Albatrellus ovinus (Fr.) Kotl. \& Pouz., Fomes fomentarius (Fr.) Fr., Fomitopsis pinicola (Fr.) Karst., Inonotus obliquus (Fr.) Pil. (sterile), Piptoporus betulinus (Fr.) Karst. and Trametes zonatella Ryv. Reference specimens were collected of all the less common species, and of the fruit bodies which could not be identified with certainty in the field. The less valuable part of this material was discarded after examination, but the collections of the rarer species and some material of all the commoner ones were saved from each locality to be preserved in the herbarium $\mathrm{H}$.

Each locality was studied as carefully as possible, and special attention was paid to the debris of dead wood on the ground. Notes were made in the field on the ecology and pathology: records of the host tree species, the vitality of the host if still living, the degree of decay, and the moisture conditions. The co-occurrence of polypore species was also noted.

\section{Occurrence and hosts}

It is almost impossible to estimate the abundance of polypores in the same way as in floristic studies of vascular plants. However, it was felt necessary to have some means of comparing abundance. A five-point scale was used for the purpose:

$\begin{array}{ll}\text { Abundance } & \text { Observations } \\ \text { scale } & \text { per area } \\ \text { very rare }(\mathrm{vr}) & 1 \\ \text { rare }(\mathrm{r}) & 2-4 \\ \text { fairly common }(\mathrm{fc}) & 5-8 \\ \text { common }(\mathrm{c}) & 9-16 \\ \text { very common }(\mathrm{vc}) & \text { over } 16\end{array}$

It must be kept in mind that this is a very rough scale, which is not equally applicable in all cases. First, the results depend on the working routine of the observer, especially as regards the resupinates. The size of the area studied directly affects the amount of observations, as does also the time spent on active research in each area. However, the sparse and haphazard occurrence of the polypores rules out the use of study plots of fixed size, unless they are very large. The abundance of a certain species may vary greatly within an area, according to the degree of moisture, the type of forest, etc., and these small-scale variations remain invisible. Reliable rating would need regular visits for many years. In spite of these drawbacks, it is hoped that this scale will help in making rough comparisons between the species.

In the section Notes, the percentage distribution on the different hosts is shown for the common species ( 9 or more observations), while for the rarer species the amounts of the collections are given.

The nomenclature of the host tree species and other vascular plants follows the list of Hämet-Ahti et al. (1980) and that of the bryophytes follows Koponen et al. (1977). The authors of the names can be found in those papers, and are not repeated here. In the text the following common names are used: pine (meaning Pinus sylvestris), spruce (Picea abies), alder (Alnus glutinosa and A. incana), aspen (Populus tremula) and birch (Betula pendula and B. pubescens). The forest site type terminology follows Cajander (1926) and Kujala (1979).

\section{Polypore nomenclature}

The nomenclature of the pore fungi is at present in an unsettled state, especially as regards the generic names. The system used here is not found in any manual, although it mostly rests on Donk (1974), Ryvarden (1976, 1978, 1980) and Jahn (1979). The classification is often based on recent separately published studies. In confusing cases important synonyms are given. The concept of the group 'Polypores' is 
interpreted in the wide traditional sense, and the genera and species are listed alphabetically, without regard to their taxonomic positions and the division into families.

\section{Herbarium material and mapping}

The collections of H, HFR, H-LA, HPP, KUO, OULU, TUR, and the reference collections of the authors were included in compiling the distribution maps. The herbarium material is valuable in delimiting the distributions, but seldom gives useful information on the ecology. Therefore the ecological notes are based mainly on our own field observations. The uniform grid system is used in the maps (cf. Heikinheimo \& Raatikainen 1971, where the Finnish biological provinces and the most important local names are also presented).

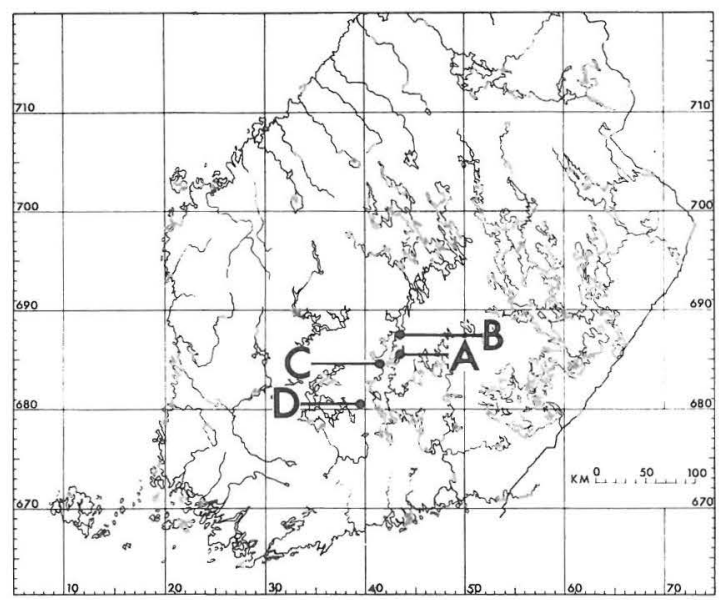

Fig. 1. The study areas.

\section{The study areas}

\section{Molikko (A)}

Etelä-Häme. Luhanka, Onkisalo

Grid $27^{\circ} \mathrm{E} 6850: 431$

The area comprises the surroundings of a small pond, Molikonlampi, and a brook draining to Lake Päijänne. It covers only $0.5 \mathrm{~km}^{2}$, most of it lying on an east-facing slope traversed by the brook.

By Lake Päijänne are big, living and dying aspen and some pines. The shore is dry and poor in vascular plants because of large stones.

Further up, the forest turns into a birch wood, where Betula pendula $(95 \%)$ is mixed with Pinus sylvestris (4\% ), Picea abies and Populus tremula. Lower woody plants are Juniperus communis, Lonicera xylosteum, Sorbus aucuparia and Tilia cordata. Common herbs and grasses are Calamagrostis arundinacea, Hepatica nobilis and Oxalis acetosella; less common are Actaea spicata, Aegopodium podagraria, Angelica sylvestris, Coeloglossum viride, Geranium sylvaticum, Lathyrus vernus, Maianthemum bifolium, Melica nutans, Paris quadrifolia, Vicia sylvatica, and the ferns Dryopteris filix-mas, Pteridium aquilinum and Thelypteris phegop- teris. The commonest mosses are Hylocomium splendens and Pleurozium schreberi, followed by Rhytidiadelphus triquetrus. Litter of dead birch leaves has kept the moss cover open.

The brook is bordered by a 20 -m-wide strip of grassherb forest, chiefly composed of southern trees (Tilia cordata over $90 \%$ and Acer platanoides); other tree species are Populus tremula, Prunus padus, Salix caprea and Sorbus aucuparia. Lonicera xylosteum and Ribes rubrum are common shrubs. The lower part of the slope is a dense thicket, with Viola mirabilis growing in the less shady places.

Near Molikonlampi the vegetation is less dense, and there are abundant shrubs, grasses, ferns and herbs: Actaea spicata, Angelica sylvestris, Athyrium filix-femina, Daphne mezereum, Dryopteris filix-mas, Elymus caninus, Galium triflorum, Hepatica nobilis, Impatiens noli-tangere, Lathyrus vernus, Maianthemum bifolium, Melampyrum sylvaticum, Melica nutans, Oxalis acetosella, Paris quadrifolia, Poa nemoralis, Thelypteris phegopteris, Trientalis europaea, Viburnum opulus, Vicia sylvatica and Viola mirabilis.

The forest around the pond Molikonlampi $(20 \mathrm{~m}$ above the water level of Päijänne ) is swampy with dead and dying pine and birch, and a littoral belt of Alnus glutinosa.

\section{Vaarunvuori (B)}

Etelä-Häme. Korpilahti, Vaarunvuori Grid $27^{\circ} \mathrm{E} 687: 43$

The area is fairly extensive, containing forest of different types. The localities investigated are small, and vary from poor Calluna-type forest to luxuriant grassherb forest rich in ferns.

In the western part of the area is a nature reserve consisting partly of pine forest and partly of mixed spruce-dominated forest with trees $100-120$ years old. In the pine forest Calluna vulgaris and Vaccinium vitisidaea are the commonest dwarf shrubs, and Calamagrostis arundinacea the dominant grass.

On the east side of the nature reserve the forest changes into mixed spruce forest. The field layer is dominated by Vaccinium myrtillus, growing with Calamagrostis arundinacea, Calluna vulgaris, Convallaria majalis, Deschampsia flexuosa, Linnaea borealis, Luzula pilosa, Maianthemum bifolium, Orthilia secunda, Oxalis acetosella, Rubus saxatilis, Trientalis europaea, Vaccinium vitis-idaea and Viola riviniana.

In the eastern part of the Vaarunvuori area there is another nature reserve, composed of grass-herb forest rich in herbs and ferns. Alnus glutinosa, Salix caprea, Tilia cordata and Ulmus glabra border a little brook, and tall birch and aspen trees grow in the northernmost part of the area. This is also the northernmost natural Finnish locality of Corylus avellana. The field layer is 


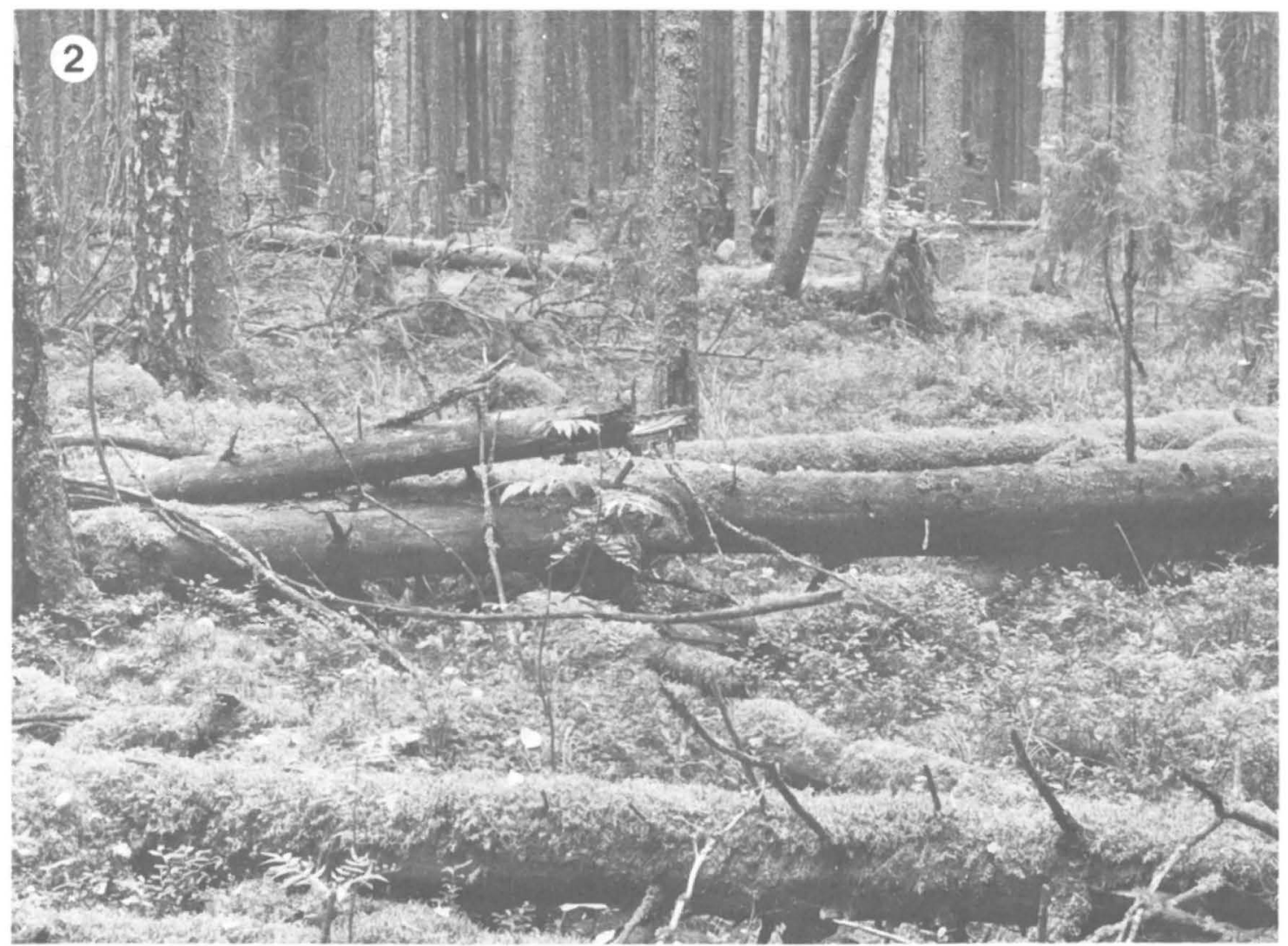

Fig. 2. A view of the northern part of the Vesijako National Park, one of the oldest and densest virgin spruce forests in Finland. The stand of spruce is intermixed with birch, and fallen trunks harbour a rich polypore flora.

composed of Actaea spicata, Athyrium filix-femina, Polypodium vulgare, Rubus idaeus, Scrophularia nodosa, Stachys sylvatica and Viola mirabilis.

Collections were also made in mixed forest west of this area.

The vegetation of the nature reserves is described by Linkola (1917) and Raatikainen et al. (1975).

\section{Edessalo (C)}

Etelä-Häme. Jämsä, Edessalo

Grid $27^{\circ} \mathrm{E} 684: 41$

The island of Edessalo in Lake Päijänne is $7 \mathrm{~km}^{2}$ in size, and the study area is $3.5 \mathrm{~km}^{2}$.

The inner parts of the island rise about $70 \mathrm{~m}$ above the water level of Päijänne. The forest varies from poor Calluna type (CT) to rich grass-herb types, the latter characterized by Actaea spicata, Athyrium filix-femina, Maianthemum bifolium, Oxalis acetosella and Scrophularia nodosa growing under Tilia cordata.

The majority of these inner parts, however, belong to the Myrtillus site type (MT). Picea abies is the predominant tree, forming stands about 100 years of age.
The biggest trunks of Pinus sylvestris are over 250 years old. The commonest grasses and dwarf shrubs in these sites are Vaccinium vitis-idaea, Calamagrostis arundinacea and Linnaea borealis, accompanied by Calluna vulgaris, Deschampsia flexuosa, Festuca ovina, Luzula pilosa, Melampyrum sylvaticum, Orthilia secunda, Solidago virgaurea and Trientalis europaea. Common mosses are Hylocomium splendens and Pleurozium schreberi.

The shores of the study area are mostly poor in vegetation and the dominant trees are Pinus sylvestris and Betula pendula, with a few Populus tremula, and Alnus glutinosa by the water's edge. Small pines and big Cladonia communities occur on the cliffs.

\section{Vesijako (D)}

- Fig. 2

Etelä-Häme. Padasjoki, Vesijako National Park

Grid 27ํㅡ 6806:398

This is the southernmost of the study areas. The park covers $1.2 \mathrm{~km}^{2}$ and is divided into two halves by a westeast road. North of the road is true virgin forest dominated by spruce, which has evidently never been felled. 
The spruce forest in the southern half has been partly cut down in 1918-1919 and 1939-1940.

Picea abies is dominant in both halves; other tree species are Alnus glutinosa, A. incana, Betula pendula, Pinus sylvestris and Populus tremula. Salix caprea and Sorbus aucuparia are scattered throughout the area. The biggest pines and spruces are over $30 \mathrm{~m}$ tall.

The field layer consists of Vaccinium myrtillus (the dominant species), Calamagrostis arundinacea, Deschampsia flexuosa, Hepatica nobilis (occasional only), Maianthemum bifolium, Melampyrum sylvaticum, Orthilia secunda, Rubus saxatilis, Solidago virgaurea, Trientalis europaea and Vaccinium vitisidaea.

Table 1. The species and their abundance in the four study areas.

Albatrellus ovinus

Amylocystis lapponica

Amyloporia xantha

Anomoporia bombycina

A. myceliosa

Antrodia plicata

A. salicina

A. serialis

A. sinuosa

Antrodiella semisupina

Antrodiella sp.

Aporpium caryae

Bjerkandera adusta

Ceriporia reticulata

C. viridans

Ceriporiopsis resinascens

Cerrena unicolor

Climacocystis borealis

Coltricia perennis

Datronia mollis

Fibroporia gossypia

Fibuloporia donkii

Fomes fomentarius

Fomitopsis pinicola

F. rosea

Ganoderma applanatum

Gloeophyllum odoratum

G. sepiarium

Gloeoporus dichrous

G. pannocinctus

Hapalopilus rutilans

$H$. salmonicolor

Haploporus odorus

Heterobasidion annosum

Incrustoporia stellae

I. subincarnata

I. tschulymica

Inonotus obliquus

I. radiatus

I. rheades

Ischnoderma benzoinum
Junghuhnia collabens

J. luteoalba

J. nitida

Lenzites betulina

Leptoporus mollis

Meruliopsis taxicola

Onnia tomentosa

O. triquetra

Oxyporus corticola

O. populinus

Parmastomyces kravtzevianus

Phellinus chrysoloma

$P$. conchatus

$P$. ferrugineofuscus

$P$. igniarius

$P$. laevigatus

$P$. lundellii

$P$. nigricans

$P$. nigrolimitatus

$P$. pini

$P$. populicola

$P$. punctatus

$P$. tremulae

$P$. viticola

Piptoporus betulinus

Polyporus brumalis

$P$. ciliatus

P. umbellatus

$P$. varius

Poria lindbladii

$P$. placenta

$P$. romellii

Pycnoporus cinnabarinus

Rigidoporus vitreus

Schizopora paradoxa

Skeletocutis amorpha

Strangulidium rennyi

S. sericeomolle

Trametes hirsuta

T. hoehnelii

T. pubescens

$T$. velutina

T. zonatella

Trechispora mollusca

Trichaptum abietinum

T. fuscoviolaceum

Tyromyces caesius

T. chioneus

T. fragilis

T. guttulatus

$T$. leucomallellus

T. lowei

$T$. stipticus

T. subcaesius 'f. minor'

T. tephroleucus

T. undosus

Total numbers of species found:

97

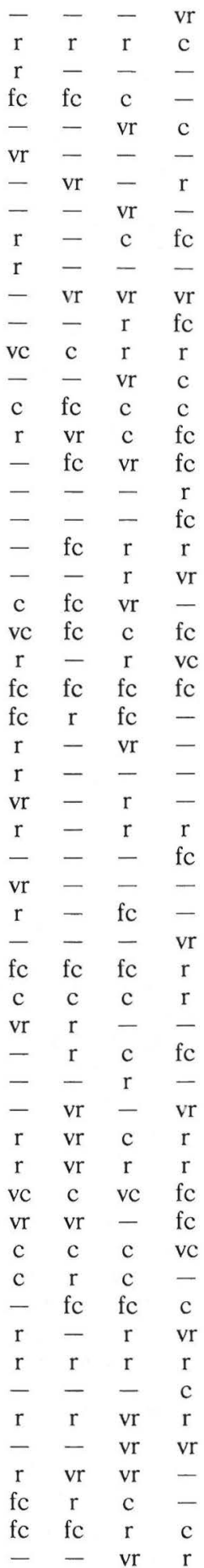

$\begin{array}{llll}57 & 57 & 70 & 69\end{array}$ 


\section{Notes on the species}

Albatrellus ovinus (Fr.) Kotl. \& Pouz.

The occurrence varied greatly between years. In 1978 only one small fruit body was noted in Edessalo. In 1979 it grew in all the areas except Molikko, which lacks suitable biotopes, i.e., spruce forests.

Amylocystis lapponica (Rom.) Sing. - Fig. 9 Picea abies $100 \%$. Locally common in the virgin part of Vesijako National Park, and also collected from nearby virgin forest outside the study area (Lammi: Evo, Kotinen nature reserve). In Finland A. lapponica is a northern species (Eriksson \& Strid 1969), and in South Finland it has been found only in very old forests, as in the present study (Table 1). The southernmost Finnish finds, dating from the 1930s, were presumably made in much older forests than exist now in that region. The northern tendency of $A$. lapponica may be caused more by the presence of old forests in Lapland than by climatic factors. This is also suggested by its occurrence in the lowland virgin forest of Białowieża, Poland (Domański et al. 1973).

Amyloporia xantha (Fr.) Bond. \& Sing.

Pinus sylvestris $50 \%$, Picea abies $25 \%$, Salix caprea $15 \%$, Populus tremula $10 \%$. Commonest in old forests on dry coniferous wood. The finds on hardwood were made in Molikko, and represent the yellow colour form, which occurs more commonly (but not exclusively) on hardwood hosts.

Anomoporia bombycina (Fr.) Pouz.

- Fig. 3

Picea abies ( 5 finds), Pinus sylvestris (2). Found fairly easily locally in the old part of Vesijako, where it was almost always growing on small, strongly decayed trunks.

\section{A. myceliosa ( Peck) Pouz.}

- Fig. 4

Pinus sylvestris (1 find). Collected in Vaarunvuori in $\mathrm{dry}$, pine forest of the VT type, whose undergrowth is characterized by Vaccinium vitis-idaea and Hylocomium splendens. An extremely rare species in North Europe ( Niemelä 1978a).

\section{Antrodia plicata Niemelä}

Populus tremula (1 find). Collected from a big, fallen tree, which also bore fruit bodies of Bjerkandera adusta, Ceriporiopsis resinascens, Datronia mollis, Phellinus tremulae and Trametes zonatella, as well as the hydnaceous fungus Creolophus cirrhatus (Fr.) Karst., and three species of the Corticiaceae. The site was microclimatically very favourable: a well-drained slope in grass-herb forest. This is the second find of $A$. plicata in Finland ( Niemelä 1978b).

\section{A. salicina (Bres.) Niemelä}

Populus tremula (3 finds). New to Finland. The spe- cies favours dry, hard, decorticated substrates: thin trunks or branches of bigger trees, not in close contact with the ground, preferably in open and at least sometimes sunny localities. A. salicina is included by Ryvarden (1976) and Ryvarden \& Johansen (1980) in A. albida (Fr. ) Donk, but in our opinion it is a distinct species characterized by small, resupinate, thin, lacunose fruit bodies with small regular pores and an ochraceous cream colour (Niemelä 1978b).

Other collections: Finland. Varsinais-Suomi. Parainen, P. tremula, 1979 Alava 19136 (TUR). - Pohjois-Pohjanmaa. Rovaniemi, Pisavaara Nat. Park, P. tremula, 1980 Kotiranta 2212 \& Niemelä 2096 (H.K., T.N. ).

A. serialis (Fr.) Donk

Picea abies $100 \%$. One of the commonest polypore species in the study areas. Its absence from Molikko is due to the lack of suitable coniferous substrates.

A. sinuosa (Fr.) Karst.

Pinus sylvestris $49 \%$, Picea abies $48 \%$, Betula 1.5\%, Populus tremula $1.5 \%$. Common in all the study areas. Chiefly a species of coniferous wood, but occurs sporadically on many hardwood species.

Antrodiella Ryv. \& Johansen

This genus was recently described by Ryvarden and Johansen (1980), and we support its use. In Europe it embraces the $A$. semisupina complex, whose taxonomy is still rather unclear (Niemelä 1981). Its species are characterized by very small spores and a hyphal system which is best called dimitic, though showing a tendency to be trimitic, since some of the thick-walled hyphae are sparsely branched. Poria romellii belongs here, but is kept in this paper under the generic name Poria, because the new combination has not yet been made. The same applies to Trametes hoehnelii.

A. semisupina (Berk. \& Curt. ) Ryv.

Betula 75\%, Populus tremula 13\%, Alnus glutinosa 6\%, Salix caprea $6 \%$. Very often found on dead fruit bodies of other polypores, or on wood previously decayed by them. Dead Fomes fomentarius was the commonest substrate, but in Vesijako the species was once noted on living Phellinus conchatus, too. Such substrates have been reported by Bondarcev (1953), Ryvarden (1968) and Niemelä (1980), but have not been recorded in, e.g., Central Europe or North America. This may be due merely to the lack of field observations, or to ecological differences or the use of the same epithet for two separate species.

\section{Antrodiella sp.}

Finland. Etelä-Häme. Padasjoki, Vesijako Nat. Park, on strongly decayed, moss-covered Picea abies on ground, together with Fomitopsis pinicola and Tyromyces tephroleucus, 20.IX. 1980 Kotiranta 2564 \& Koski (H.K.).

Fruit body effused, or very narrowly reflexed, (0.3-) 
$2-5.5 \times(0.3-) 1-1.5 \mathrm{~cm}$ wide, less than $1 \mathrm{~mm}$ thick. Subiculum and upper surface straw-coloured. Pores pale yellow to citrine, 3-4 (-5) per mm, mouths dentate (under lens $\times 50$ ). Spores $3 \times 2 \mu \mathrm{m}$.

In view of the large pores and yellow colour, this can hardly be included in $A$. semisupina. No name has been found for this species so far.

Aporpium caryae ( Schw.) Teix. \& Rog.

Populus tremula ( 1 find). On a big, fallen tree. Niemelä (1978a) reports that $A$. caryae often occurs together with other wood-rotting fungi, but here no such association could be observed. Six Finnish localities were listed by Niemelä (1978a).

Other collections: Finland. Etelä-Häme. Lahti, on Betula together with Fomes fomentarius, Inonotus obliquus and Phellinus igniarius, 1980 Haikonen 459 (H). - Etelä-Savo. Luumäki, on rotten trunk, 1979 Fagerström $(\mathrm{H})$.

Bjerkandera adusta ( Fr.) Karst.

Betula 56\%, Populus tremula 26\%, Alnus 9\%, Picea abies $9 \%$. The species was most common in Molikko and Edessalo, where there are enough suitable hosts. $B$. adusta is fairly common in southern Finland, growing mostly on hardwood, but also on newly cut spruce stumps (Hallaksela 1977).

\section{Ceriporia reticulata (Fr.) Domański}

Corylus avellana (2 finds). This small, reticulate species was collected in Vaarunvuori in grass-herb forest, the two finds being close to each other. One of the fruit bodies grew on dead Hymenochaete tabacina (Fr.)Lév.

C. viridans (Berk. \& Br.) Donk

Betula (3 finds), Populus tremula (2). Found in birchdominated forests.

Ceriporiopsis resinascens ( Rom.) Domański

Populus tremula ( 5 finds). As pointed out by Ryvarden (1978), the spore size in the North European material varies considerably, being longer $(6-8 \mu \mathrm{m})$ in the north, and shorter $(4-6.5 \mu \mathrm{m})$ in the south. The present material is closest to the short-spored group.

Cerrena unicolor ( Fr.) Murr.

Betula $100 \%$. Absent only from the oldest parts of the Vesijako forest: the habitats are usually sunny and warm, e.g., forest margins and clearings, where it often grows together with Trametes hirsuta and $T$. zonatella.

Climacocystis borealis ( Fr.) Kotl. \& Pouz. - Fig. 10 Picea abies ( 1 find). The only collection was a small fruit body growing on a spruce stump. The fruiting of $C$. borealis varies greatly from year to year, which may be the reason for the deviating opinions of its abundance. Eriksson (1958) found only one fresh fruit body in the Muddus National Park, North Sweden, though he recorded overwintered fruit bodies from several localities. Norokorpi (1979) did not find C. borealis in spruce forests in North Finland, and disagreed with Niemelä's (1976) observation that the species is common in old forests there. We made numerous collections of $C$. borealis in northern Finland during the autumns of 1979 and 1980 .

Coltricia perennis (Fr.) Murr.

5 finds. All the fruit bodies grew on disturbed, sandy soil.

\section{Datronia mollis ( Somm. ) Donk}

Populus tremula 40\%, Betula 31\%, Salix 11\%, Sorbus aucuparia 9\%, Acer platanoides 3\%, Corylus avellana $3 \%$, Prunus padus 3\%.D. mollis was found in all the localities, except Vesijako, where its absence was evidently due to the scarcity of suitable hosts.

Fibroporia gossypia (Speg.) Parm.

Pinus sylvestris ( 1 find ). The collection is from rather hard, decorticated, fallen pine. There has been some confusion regarding the identity and nomenclature of this species. In this paper the specific concept of Ryvarden (1976) has been followed.

\section{Fibuloporia donkii Domański}

Betula (1 find), Picea abies (1), Pinus sylvestris (1), Salix (1). All the substrates were strongly decayed. A rare species in this area.

Fomes fomentarius ( Fr.) Fr.

Betula $92 \%$, Alnus 4\%, Salix caprea 3\%, Populus tremula $1 \%$. In the Vesijako National Park F. fomentarius often occurred together with Armillariella sp., characteristically on the upper parts of dead, standing trees, evidently killed by Armillariella, which had infected their bases.

Fomitopsis pinicola ( Fr.) Karst.

Picea abies $42 \%$, Betula 22\%, Pinus sylvestris 20\%, Alnus $8 \%$, Tilia cordata 4\%, Populus tremula 3\%, Salix caprea $1 \%$. A very common species throughout the study area. In Vesijako it and Heterobasidion annosum are the most common rot-causing polypores on spruce.

F. rosea (Fr.) Karst. - Fig. 11 Picea abies ( 5 finds). In Vesijako, and also, though less often, in Edessalo $F$. rosea was growing together with Amylocystis lapponica, Phellinus ferrugineofuscus and Phlebia centrifuga Karst. These host trees mostly seem to be killed by Fomitopsis pinicola. In the Muddus National Park Eriksson (1958) often found Phlebia centrifuga together with $F$. rosea and $P$. ferrugineofuscus. These species form a characteristic association on big, fallen, partly corticated spruces in old forests. This association is even more common in the northern part of the country. Eriksson and Strid (1969) consider $F$. rosea to be a northern species in Finland, but it is found all over the country, though most abundant in 
the north. Besides old forests, the sites of the southern records have often been old piles of barked timber.

Ganoderma applanatum (S.F. Gray) Pat. - Fig. 7 Betula (4 finds), Populus tremula (3), Salix caprea (1). In Molikko the pore surfaces of some fruit bodies were full of insect galls, which in Germany are known to be caused by a species of Diptera (Platypezidae), Agathomyia wankowiczi Schnabl ( Jahn 1963, 1979). Whether they are caused by the same insect in Finland is not yet known. A. wankowiczi has not been reported from Finland.

\section{Gloeophyllum odoratum (Fr.) Imazeki}

Picea abies $100 \%$. Fairly common in luxuriant habitats, growing mostly on upper sawn surfaces of old spruce stumps.

G. sepiarium ( Fr.) Karst.

Picea abies 67\%, Populus tremula 23\%, Pinus sylvestris $10 \%$. Prefers warm, sunny localities, e.g., forest clearings, so that its general abundance was not evident in this study, devoted to closed forests. It is a pioneer species on newly cut stumps, branches and felled trunks.

Gloeoporus dichrous ( Fr.) Bres.

Betula $67 \%$, Alnus glutinosa 11\%, Populus tremula $11 \%$, Salix $11 \%$. Found almost exclusively on dead fruit bodies of Inonotus obliquus or on wood decayed by it. This association has been noted by several authors in Europe (Eriksson 1958, Ryvarden 1968, 1976, Eriksson \& Strid 1969, Strid 1975, Jahn 1979, Niemelä 1980): in North America it often grows together with Ganoderma applanatum and Inonotus dryophilus ( Berk. ) Murr. (Overholts 1953).

G. pannocinctus (Rom.) Erikss.

? Tyromyces hyalinus (Berk.) Ryv., cf. Ryvarden \& Johansen (1980).

Populus tremula (5 finds), Betula (2). First reported from Finland by Ryvarden (1971), this species has been found to have scattered occurrences all over the country. We have retained the familiar epithet pannocinctus, because its identity with $T$. hyalinus has not been established with certainty.

Hapalopilus rutilans ( Fr.) Karst.

Betula $100 \%$. In southern and Central Finland H. rutilans occurs on Sorbus aucuparia in addition to birch, which is its sole host in the northern part of the country.

H. salmonicolor (Berk. \& Curt. ) Pouz.

Pinus sylvestris ( 3 finds). Two of these collections were made from trees which had been cut down. The species may be a weak competitor, which does best on a freshly cut, uninfected substrate and cannot thrive on wood strongly infected by other fungi.
Haploporus odorus (Somm.) Bond. \& Sing.

Salix caprea ( 1 find), on a living tree. $H$. odorus seems to prefer moist forests. The find at Edessalo was made in a moist depression in spruce forest bordering a small bog. The vegetation is relatively luxuriant (OMT forest site), the undergrowth being characterized by Dryopteris carthusiana, Melica nutans, Oxalis acetosella and Vaccinium myrtillus. This good-smelling species is at present rare in Finland, mostly because its sole host, Salix caprea, is almost invariably removed from managed forests, and old trees can hardly be found outside nature reserves (cf. Niemelä 1971).

Heterobasidion annosum (Fr.) Bref.

Picea abies ( 7 finds). This is the worst conifer-rotting polypore in southern Finland (Kallio \& Norokorpi 1972, Kallio \& Tamminen 1974, Laine 1976). In the present study areas, however, it was recorded as rare in Edessalo, and open gaps in the forest caused by the species were found only in Vesijako.

\section{Incrustoporia stellae (Pil.) Domański}

Picea abies (2 finds). Found in Vesijako on fallen spruces $200 \mathrm{~m}$ apart. I. stellae is very rare in South Finland but less rare in Lapland. Everywhere it seems to need old, rich spruce forests. Eriksson and Strid (1969) consider it a good representative of the 'taiga species', by which they mean species that have their main distribution in the boreal, continental parts of Eurasia. The distribution of $I$. stellae seems to fit with this concept, although there are also scattered occurrences in Central Europe.

\section{I. subincarnata (Peck) Domański}

Pinus sylvestris 76\%, Picea abies 24\%. This species often grows on fairly fresh pine branches and small fallen spruces. Although it is found in all types of forests, it and Antrodia sinuosa are among the most characteristic and common resupinate polypores on dry pine heaths.

\section{I. tschulymica (Pil.) Domański}

Picea abies (1 find), Populus tremula (1). Fruit bodies of Leptoporus mollis and Phellinus viticola were also found on the spruce. The species is fairly common in North Finland, where it always grows on dead Picea abies. In South Finland it has scattered occurrences, being found fairly often on aspen besides spruce. No macroscopical or microscopical characters were found which suggested that two taxa were involved. It should be noted that the type of I. tschulymica (in PRM) is from aspen. Eriksson and Strid (1969) regard this as a 'taiga species' as well, but it has a less distinctly northern continental distribution than I. stellae: I. tschulymica has been fairly widely collected, e.g., in Central and even South Europe. 


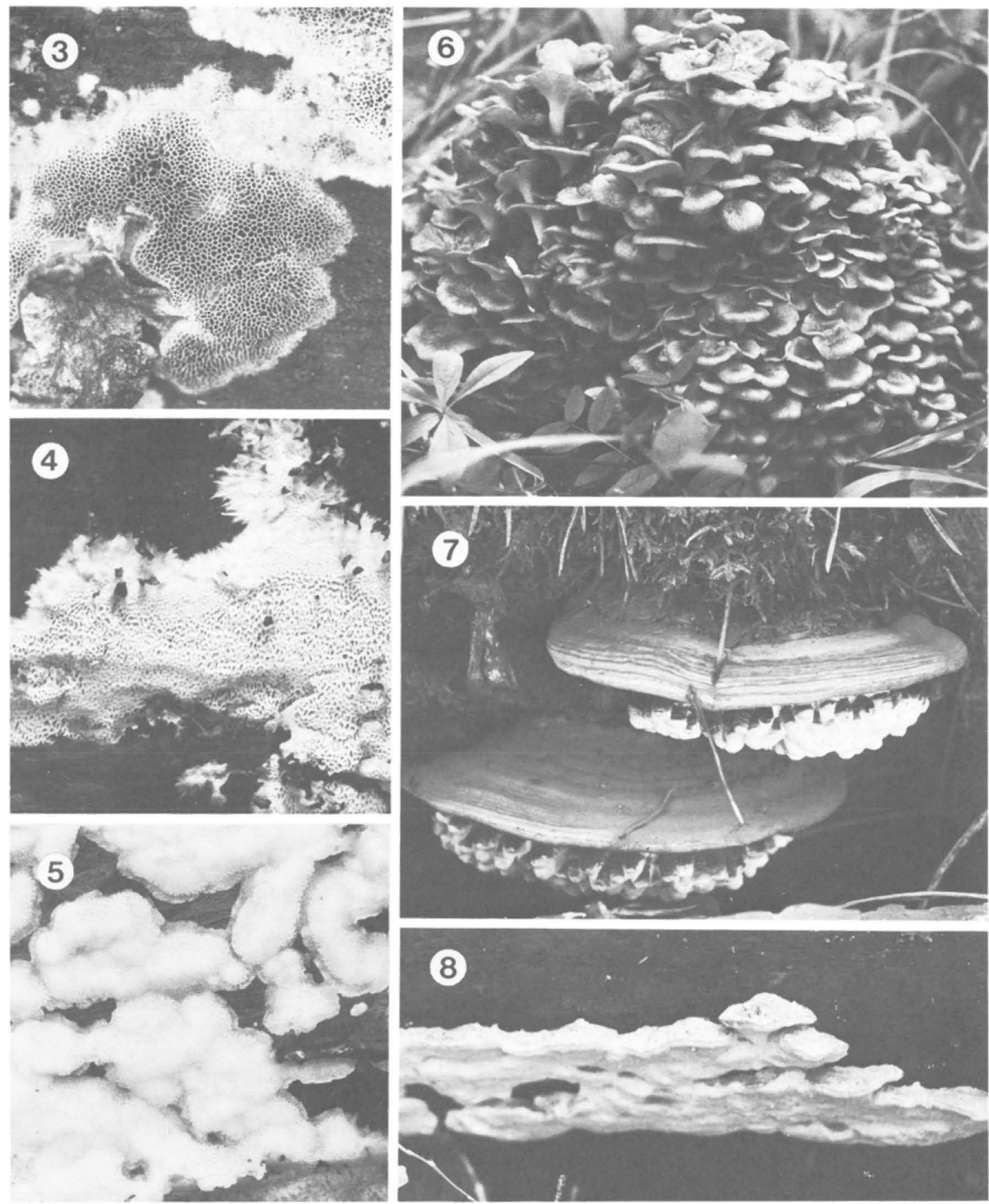

Figs. 3-8. -3: Anomoporia bombycina on Picea abies (Vesijako Nat. Park, Kotiranta 2599 \& Koski, H), X 1.2. -4: A. myceliosa on Picea abies (Vesijako Nat. Park, 1981 Kotiranta 2886, H and H.K.), X 1. Found after the writing, this specimen is not included in the text. - 5: Rigidoporus vitreus on strongly decayed, wet Picea abies (Vesijako Nat. Park, Kotiranta 2610 \& Koski, H), X 0.9. - 6: Polyporus umbellatus in grass-herb forest (Molikko, 1977 Kotiranta, H), X 0.2. - 7: Ganoderma applanatum with insect galls evidently caused by Agathomyia wankowiczi (Molikko, Niemelä 1699 \& Kotiranta, T.N.), X 0.8 . 8: Tyromyces leucomallellus on decorticated Picea abies (Vesijako Nat. Park, Kotiranta 2885, H and H. K.), X 0.2 . 
Inonotus obliquus (Fr.) Pil.

Betula $100 \%$. Only two of the finds were fertile fruit bodies, the others were sterile conks on living trees. The short-living resupinate fruit bodies are rather seldom found, especially in the southern part of the country. In Finland I. obliquus is most common on birch, but also occurs on Alnus and less often on other hardwood species.

I. radiatus (Fr.) Karst.

Alnus $80 \%$, Corylus avellana $13 \%$, Betula $7 \%$. This species is most abundant in lake shore alder thickets, but these were poorly represented in this study.

\section{I. rheades (Pers.) Karst.}

Populus tremula ( 7 finds). Grows most often on fallen, rather thick and dry branches of aspen, also sometimes on dead standing or fallen trunks. It is very seldom found on living trees, and no such records were made in this study.

Ischnoderma benzoinum (Wahl. ) Karst.

Picea abies $78 \%$, Pinus sylvestris $22 \%$. Often grows on old, moss-covered stumps of spruce.

Junghuhnia collabens ( Fr.) Ryv.

Picea abies ( 1 find). Not found during the present field studies, but collected once before (Padasjoki, Vesijako Nat. Park, on fallen and strongly decayed trunk of Picea abies, 1966 Laine \& Niemelä, HFR, T.N.) This species is somewhat less rare in Lapland, and is found only in moist and dense spruce forests. It causes an intensive, net-like decay on spruce.

J. luteoalba ( Karst.) Ryv.

Pinus sylvestris $71 \%$, Picea abies $29 \%$. Together with Antrodia sinuosa and Incrustoporia subincarnata, this is a characteristic species of dry pine heaths (CT and VT forest sites). The host trees of $J$. luteoalba are usually decorticated, and bigger and more strongly decayed than the hosts of the others.

J. nitida (Fr.) Ryv.

Populus tremula (4 finds). A rare species, which, however, may be very abundant when present: once the whole under side of a trunk was covered by fruit bodies of this polypore. It prefers a rather dry substrate.

Lenzites betulina (Fr.) Fr.

Betula $78 \%$, Populus tremula $22 \%$. Often grows together with Cerrena unicolor and Trametes zonatella and is more common in disturbed than old forests.

Leptoporus mollis (Fr.) Quél.

- Fig. 12

Picea abies $94 \%$, Pinus sylvestris $6 \%$. The proportions of the occurrences on spruce and pine change gradually in Finland: in the south the commonest host is Pinus sylvestris, while in North Finland it occurs exclusively on Picea abies. The northernmost collection on pine is from Pohjois-Karjala, Tuupovaara. The present region falls between the two extremes.

This species, anatomically closely related to the genus Ceriporia, was separated from Tyromyces by David (1980).

Meruliopsis taxicola (Pers.) Bond.

Pinus sylvestris (1 find). Eriksson and Strid (1969) pointed out that there may be two taxa under this name in Fennoscandia: a northern one growing on fallen spruces, and a southern one with a lighter colour and smaller size, which grows on branches high in living pine trees. Although growing on pine, the present specimen was similar in morphology and ecology to the northern type from spruce.

Onnia tomentosa (Fr.) Karst.

5 collections. This species is regarded as a root parasite of coniferous trees. The present finds were made in mixed spruce - pine forests, and no association with a certain tree species could be established. The find from Vaarunvuori is the northernmost known in Finland: Norokorpi's (1979) report that O. tomentosa is a northern species must be due to a misunderstanding of the species concept or incorrect determinations.

O. triquetra ( Lenz) Imazeki

Pinus sylvestris ( 1 find). New to Finland. The fruit bodies were young, but nevertheless showed the characteristic robust structure and hooked setae of $O$. triquetra. This is a southern species, associated with pine, and fairly close to the northern, spruce-inhabiting species O. leporina ( Fr.) Jahn, which was not found in the present study. Concerning the genus Onnia, the nomenclature and species concepts of Jahn (1978) were followed here.

Oxyporus corticola (Fr.) Ryv.

Populus tremula 94\%, Betula 6\% . O. corticola is generally a fairly common species on big, fallen, corticated aspens. In Edessalo it was once growing together with Gloeophyllum sepiarium, Trametes zonatella and Tyromyces subcaesius' 'f. minor'.

O. populinus (Fr.) Donk

Acer platanoides ( 2 finds). The fruit bodies were found on living trees in hardwood forest beside a brook. The species is common on park trees in South Finland, but has scattered occurrences up to the northernmost part of the country.

Parmastomyces kravtzevianus (Bond. \& Parm.) Kotl. \& Pouz.

Tyromyces subcartilagineus ( Overh.) Domański Pinus sylvestris ( 3 finds ). One earlier record from Finland ( Ryvarden 1976). The Edessalo collection is from a charred 250-year-old chump, where the species was growing together with Strangulidium sericeomolle. 
The known Finnish collections: Uusimaa. Ruotsinpyhtää, on $\log$ of Pinus sylvestris together with Incrustoporia subincarnata and S. sericeomolle, 1979 Kotiranta 1848 (H.K.). Etelä-Häme. Jämsä, Edessalo, Pinus sylvestris, 1979 Kotiranta 1540 (H.K., T.N.). Korpilahti, Vaarunvuori, P. sylvestris, 1979 Kotiranta 1643 (H.K., T.N.). Padasjoki, Vesijako Nat. Park, P. sylvestris, 1979 Kotiranta 1124 (H.K.). - EteläSavo. Savitaipale, P. sylvestris, 1967 Laine, Wikström \& Niemelä (T.N.).

Phellinus chrysoloma (Fr.) Donk

Picea abies ( 7 finds). One of the commonest basidiomycete species causing butt rot in old spruce stands (Norokorpi 1979). In the present areas, however, it is fairly common only in the oldest forests, and even there rarer than Fomitopsis pinicola and Heterobasidion annosum.

P. conchatus (Fr.) Quél.

Salix caprea 95\%, Populus tremula 5\%, ?Tilia cordata.

P. ferrugineofuscus (Karst.) Bourd.

Picea abies $100 \%$. Ecologically fairly similar to Amylocystis lapponica and Fomitopsis rosea. In southern Finland it occurs almost exclusively in very old or virgin forests, and it becomes commoner towards the north. In Lapland it is one of the main decay-causing fungi on fallen spruces (Eriksson 1958).

P. igniarius (Fr.) Quél.

Betula $87 \%$, Alnus 9\%, Salix 2\%, Ulmus glabra 2\%. Common in all the areas wherever suitable hardwood hosts were present.

P. laevigatus (Fr.) Bourd. \& Galz.

Betula $100 \%$. A scattered species, which was most easily found on fallen, corticated birch trunks in dense, old or virgin spruce-dominated forests.

\section{P. lundellii Niemelä}

Betula $67 \%$, Alnus 33\%. Also rather a scattered species in the study areas, and, like $P$. laevigatus, commoner in the northern parts of the country.

P. nigricans (Fr.) Karst.

Betula (2 finds). P. nigricans is easily overlooked, since it greatly resembles $P$. igniarius, which is commoner in southern Finland. $P$. nigricans becomes more frequent towards the north, and favours old untouched forests (Niemelä 1975).

P. nigrolimitatus ( Rom. ) Bourd. \& Galz.

Picea abies ( 7 finds). A northern species, which according to Eriksson (1958) is one of the most important fungi causing decay on old fallen spruces in Lapland. In our study area it was found on moss-covered, strongly decayed fallen trunks. In southern Finland it is primarily found in dense virgin forests, in the polypore communities characterized by Amylocystis lapponica, Fomitopsis rosea, Incrustoporia stellae and Phellinus ferrugineofuscus. Oddly enough, it resembles $F$. rosea in often being collected from old piles of barked timber.
P. pini (Fr.) Ames

Pinus sylvestris $100 \%$. Almost all the fruit bodies were observed on big, healthy-looking pine trees. It occurs regularly in the areas, though in small numbers.

\section{P. populicola Niemelä}

Populus tremula ( 3 finds). All the collections are from big, living trees. This is a rare satellite species of $P$. igniarius (rather than $P$. tremulae, Niemelä 1975), which can reach a remarkable size.

P. punctatus (Fr.) Pil.

Salix caprea 69\%, Prunus padus 13\%, Alnus 6\%, Corylus avellana 6\%, Populus tremula 6\%. The species is fairly common in hardwood forests at early stage of succession (e.g., Molikko), but is very rare or absent from the shady forests of the climax stage (e.g., Vesijako). A common species in Finland, with a very wide spectrum of host trees.

\section{P. tremulae (Bond.) Bond. \& Borisov}

Populus tremula $100 \%$. A fairly regular polypore wherever aspen trees occur. The host trees generally look healthy, but in fact the presence of the fruit bodies indicates extensive heart rot. Distributed all over the country (Niemelä 1974).

P. viticola (Fr. ) Donk

P. isabellinus (Fr.) Bourd. \& Galz.

Picea abies $87 \%$, Pinus sylvestris 13\%. Among the species which prefer old forests in South Finland, and, not surprisingly, found most easily in the virgin part of the Vesijako National Park.

Piptoporus betulinus (Fr.) Karst.

Betula $100 \%$. Although fairly common in all the areas studied, $P$. betulinus did not seem to be one of the worst decay-causing polypores on birch. However, due to its annual fruit bodies, which may not arise every year, the presence of the species cannot always be easily demonstrated. In Finland it is generally regarded as one of the most important pathogens of birch.

\section{Polyporus brumalis Fr.}

Betula $71 \%$, Sorbus aucuparia 15\%, Populus tremula $7 \%$, Salix caprea $7 \%$.P. brumalis often grows on small, rather dry, fallen branches. It seems to favour young forests.

P. ciliatus Fr. (incl. f. lepideus (Fr.) Kreisel)

Betula (2 finds), Populus treinula (2). Distinctly less common than $P$. brumalis, though the fewer observations of this species may be partly caused by its springtime fruiting maximum. The study areas were searched most intensively in the autumn.

\section{P.umbellatus Fr. - Figs. 6, 13}

3 localities in Molikko. The species has appeared yearly in the brook-side grass-herb forest, dominated by birch mixed with Tilia cordata and some pines. One of the 
finds was made in a very different site: a boggy lake shore under pine and some birch, on ground covered by Sphagnum girgensohnii. P. umbellatus fruits mainly in August, and its fruit bodies seem to be very short-lived. For the hosts, see Niemelä (1978a).

Other collections: Finland. Varsinais-Suomi. Houtskari, Sördö, 1938 Kari (H). - Etelä-Häme. Kuhmoinen, on very old stump, 1978 Hukki (H). - Pohjois-Karjala. Kiihtelysvaara, in spruce forest, $1978 \mathrm{Kirsi}$ (H, T.N.).

P. varius Fr.

Populus tremula (2 finds), Betula (1).

Poria lindbladii (Berk.) Cooke

Picea abies ( 4 finds), Populus tremula (2), Pinus sylvestris (1). The species often grows on strongly decayed wood with bark still attached. It is characterized by a smell reminiscent of bedbugs and a beautifully silvercoloured pore surface in old fruit bodies.

\section{P. placenta(Fr.) Cooke}

Picea abies ( 6 finds). The characteristic light lilac colour is not always evident: it was seen in the specimens collected from Vesijako by Niemelä (1978), but those found by Kotiranta during the present study were pale yellow rather than light red. The specimens in Lapland more regularly develop the pinkish hue. The many recent collections from North Finland have shown that $P$. placenta is somewhat less rare than was previously believed.

\section{P. romellii Donk}

Populus tremula (1 find). This species belongs to the difficult Antrodiella semisupina complex, and is characterized by thin, totally resupinate fruit bodies with a patchy and indistinct margin. Inclusion in the genus Antrodiella is left for the time being, until the rank and limits of this taxon have been more clearly worked out.

Pycnoporus cinnabarinus (Fr.) Karst.

Betula ( 7 finds), Tilia cordata (1). This bright-coloured species favours open and sunny sites: forest edges, clearings and partly burned areas. Therefore it was less common in the present material than generally in Finland.

Rigidoporus vitreus (Fr.) Donk - Fig. 5 Picea abies ( 1 find). New to Finland. The species concept is according to Ryvarden (1978), who treats $R$. undatus (Pers.) Donk as a synonym. The fruit bodies are strongly hygrophanous, bluish-white when fresh, turning slowly rust-coloured when touched and drying. A rare species of strongly decayed, moist substrates.

Schizopora paradoxa (Fr.) Donk

Betula $69 \%$, Populus tremula 15\%, Salix caprea $8 \%$, Sorbus aucuparia $8 \%$. A very common species in South Finland, but occurs in favourable biotopes up to northern Finland (Eriksson \& Strid 1969).
Skeletocutis amorpha (Fr.) Kotl. \& Pouz.

Pinus sylvestris $71 \%$, Picea abies 29\%. Grows mostly on thick bark on stumps.

Strangulidium rennyi (Berk. \& Br.) Pouz.

Pinus sylvestris (2 finds), Picea abies (1). New to Finland. S. rennyi grows on the under sides of fallen trunks which lie very close to the ground, and the fruit bodies are seen only when the whole trunk is turned over. The species closely resembles $S$. sericeomolle, but lacks cystidia and has cream-coloured masses of chlamydospores at the margins and in the subicular cavities.

S. sericeomolle ( Rom.) Pouz.

Pinus sylvestris 58\%, Picea abies $42 \%$. Often found growing on old, charred wood, and also on dry pine heaths, in the same way as in North Finland (Eriksson \& Strid 1969).

Trametes hirsuta (Fr.) Pil.

Alnus (2 finds), Betula (1), Picea abies (1). The observation on spruce is exceptional, though not impossible: a Finnish collection from Juniperus communis is also known to us. The ecological similarities of the three hirsute species $T$. hirsuta, Cerrena unicolor and Lenzites betulina is curious. They are all most often met with in sunny places. It may be that the thick cover of hairs protects the fruit bodies against desiccation and heat.

T. hoehnelii (Bres.) Pil.

Betula (1 find). Collected from Vaarunvuori on an alder decayed by Fomitopsis pinicola and Inonotus radiatus, and from Vesijako on a birch decayed by Fomes fomentarius. The first-mentioned locality is the northernmost known in Finland. See the note on the genus Antrodiella.

T. pubescens (Fr.) Pil.

Betula 65\%, Populus tremula 23\%, Alnus 6\%, Picea abies 6\%.

T. velutina (Fr.) Cunningh.

Betula $78 \%$, Corylus avellana 11\%, Populus tremula $11 \%$. Contrary to the common practice, we have separated these two taxa. By $T$. velutina we mean the sharpedged, thin and soft taxon which has a silky pure white upper surface, is loosely attached to the substrate and disintegrates soon after sporulation. T. pubescens in the strict sense is more robust and hardy, is cream-coloured and has a densely pubescent upper surface. At least in these areas the two are generally easily separated from each other.

\section{T. zonatella Ryv.}

Coriolus zonatus (Fr.) Quél.

Betula 54\%, Populus tremula 42\%, Picea abies 3\%, Alnus $1 \%$. Varies in abundance even in the study areas, but reaches its maximal occurrence in places strongly influenced by man. 

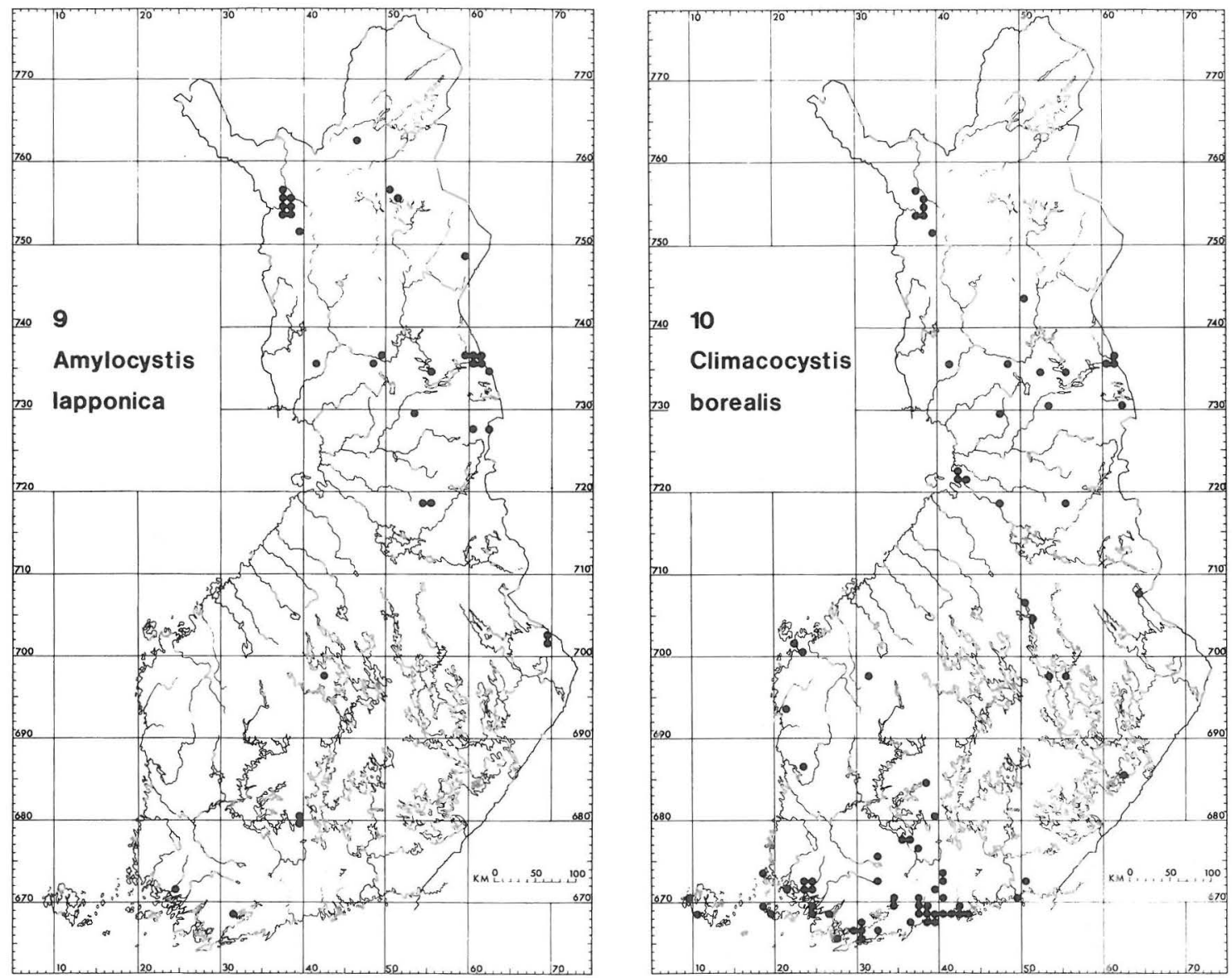

Figs. 9-10. The distribution of Amylocystis lapponica and Climacocystis borealis in Finland.

Trechispora mollusca (Fr.) Liberta Cristella mollusca (Fr.) Donk

Pinus sylvestris ( 5 finds), Betula (3). Collected on strongly decayed substrates, and once on dead fruit bodies of Fomes fomentarius.

Trichaptum abietinum (Fr.) Ryv. Hirschioporus abietinus (Fr.) Donk

Picea abies 49\%, Pinus sylvestris 49\%, Betula 2\%. A characteristic pioneer species, which rapidly appears on fallen trees (Jahn 1979).

T. fuscoviolaceum (Fr.) Ryv.

\section{Hirschioporus fuscoviolaceus (Fr.) Donk}

Pinus sylvestris $100 \%$. Less common than T. abietinum in these areas, and mostly restricted to Pinus, but also occurring on spruce, and occasionally on hardwood in Finland. It seems to favour somewhat more open localities than T. abietinum.
Tyromyces Karst.

This is a collective genus, interpreted in a different way almost every time that it is treated. In a wide sense (e.g., Lowe 1975, Ryvarden 1978) it embraces almost all lightcoloured polypores with a monomitic hyphal structure and clamp connections. It is, however, evident that it contains unrelated elements even in the restricted sense applied here. The division of the genus commenced by David (1980) has been followed here only with regard to Leptoporus. Her concept of Spongiporus seems sound, but has not been adopted here, because some of our species have not been included in that genus, and older generic names seem to be available for that group, e.g., Podoporia Karst. We plan to return to these problems in a later paper. Some specimens probably belonging to this genus in the present material had to be left unidentified for various reasons, e.g., because they were too young or too old. 

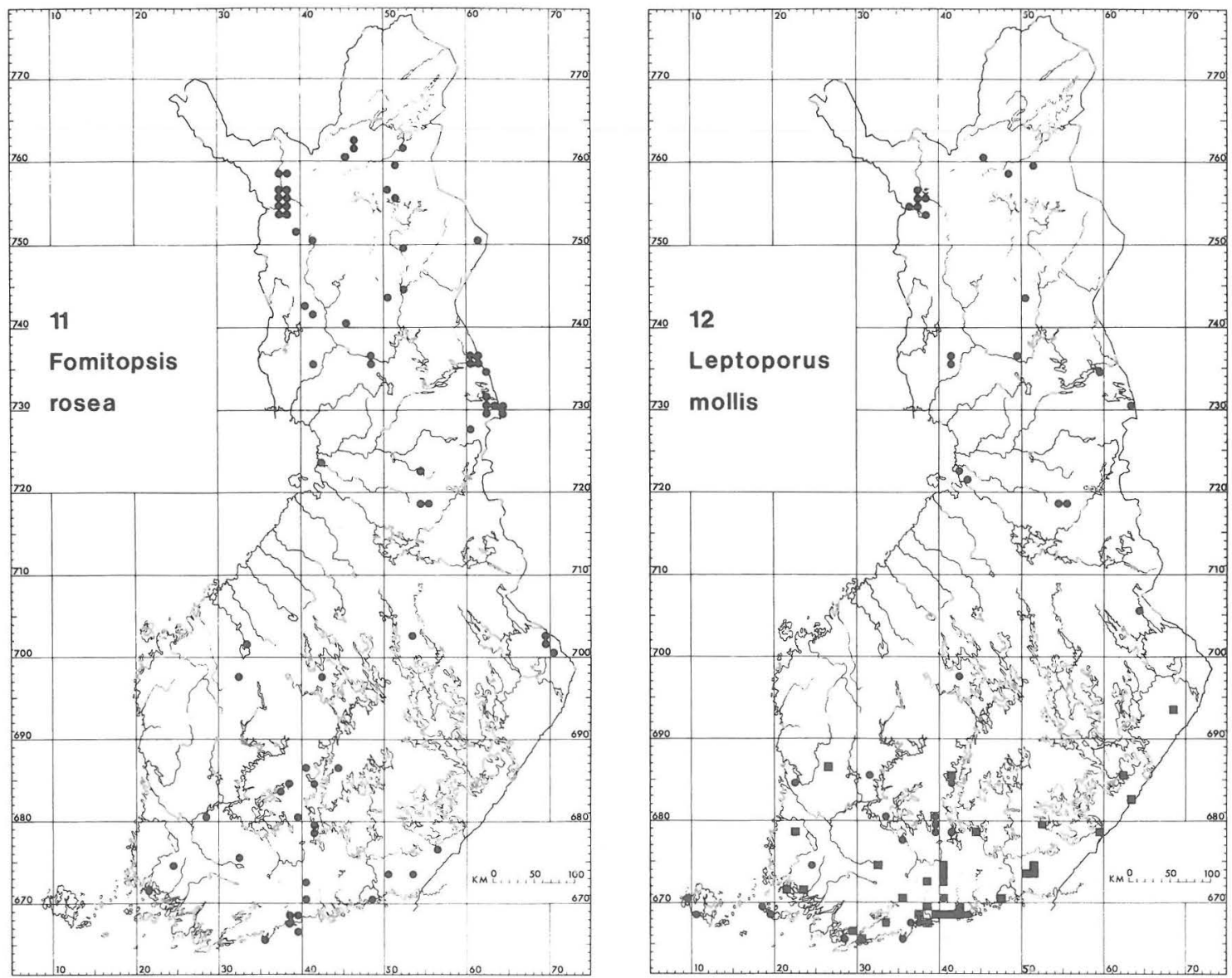

Figs. 11-12. - 11: The distribution of Fomitopsis rosea in Finland. - 12: The distribution of Leptoporus mollis on spruce (dots) and pine (squares) in Finland.

T. caesius ( Fr.) Murr.

Picea abies $85 \%$, Pinus sylvestris $15 \%$. Common on rather small, fairly recently fallen trunks of pine and spruce.

\section{T. chioneus ( Fr.) Karst.}

Tyromyces albellus (Peck) Bond. \& Sing.

Betula $67 \%$, Sorbus aucuparia $22 \%$, Alnus incana $11 \%$.

\section{T. fragilis (Fr.) Donk}

Picea abies $57 \%$, Pinus sylvestris $43 \%$. Easily identified immediately in the field because of the rapid change of colour. When touched it turns first yellow and then deep rust, and the paper collecting bags are also stained brown. The colour change is more rapid and intense than in $T$. leucomallellus.

\section{T. guttulatus ( Peck) Murr.}

Picea abies $82 \%$, Pinus sylvestris $18 \%$. The fruit bodies often grew on old wood, covered by grasses and herbs; once it was found at the base of a living spruce. One record was from a stump decayed by Fomitopsis pinicola. This rare (Niemelä 1978a) species fruits in Vesijako as early as July.

T. leucomallellus Murr.

- Figs. 8, 14

Pinus sylvestris $100 \%$. Predominantly a southern species (Niemelä 1978a), but perhaps not so rare as believed before.

\section{T. lowei (Pil.) Domański}

Picea abies ( 2 finds). New to Finland. Resembles $T$. leucomallellus, but differs in being smaller and more fragile, and lacking gloeocystidia. Further, the upper surface develops dark rusty flecks even in nature, and finally becomes entirely warm rust brown, while the tubes remain almost white. Occurs mostly in very dry sites.

T. stipticus (Fr. ) Kotl. \& Pouz.

Picea abies (2 finds), Betula (2). 

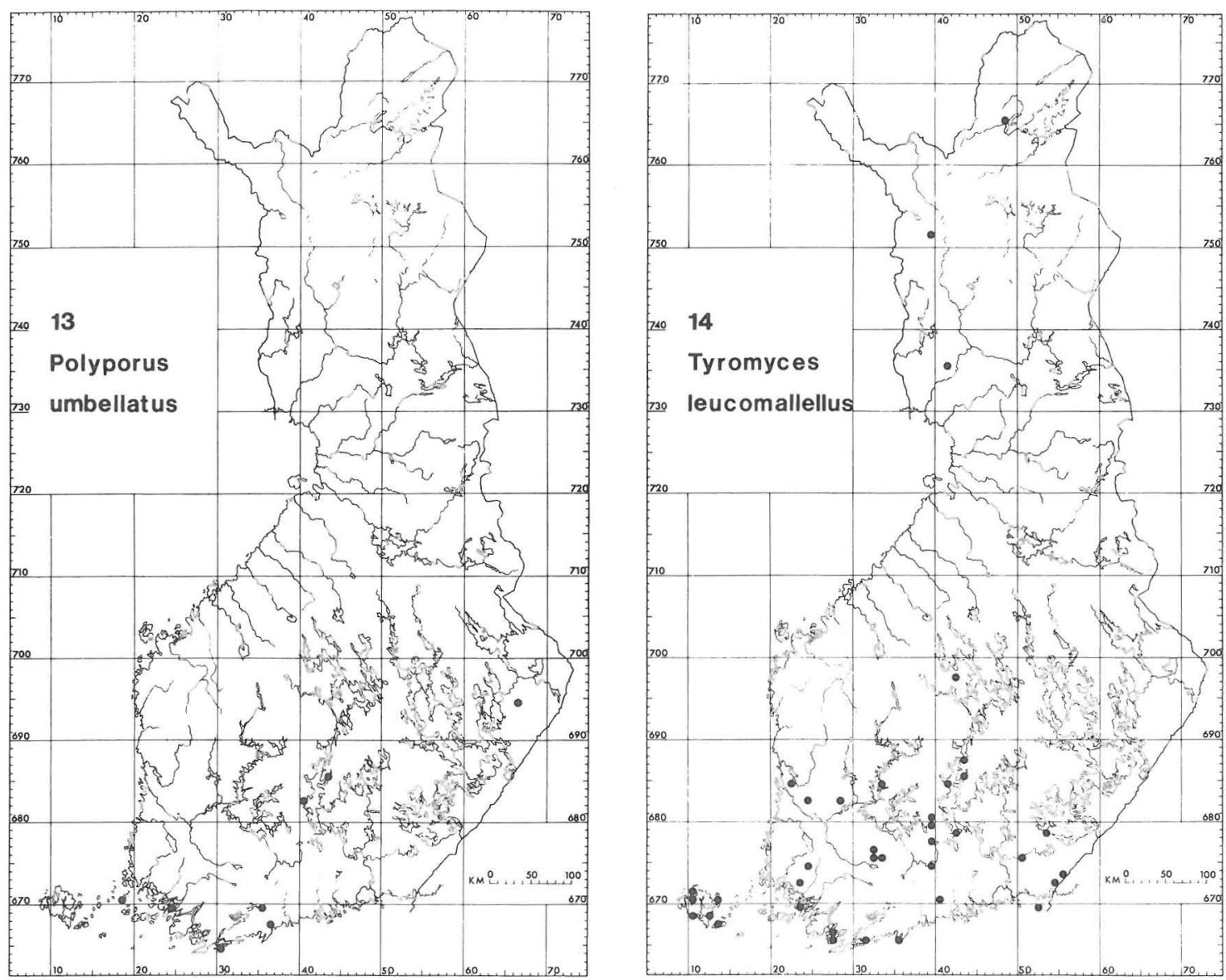

Figs. 13-14. The distribution of Polyporus umbellatus and Tyromyces leucomallellus in Finland.

T. subcaesius David 'f. minor Jahn'

Populus tremula $90 \%$, Betula 10\%. This is the hardwood-dwelling counterpart of $T$. caesius. Its taxonomy is still far from settled, and only the provisional name ' $\mathrm{f}$. minor' is available for it. The taxon is definitely not $T$. subcaesius in the strict sense, although this name has been used (Strid 1975). The differences between this and T. caesius are described well by Jahn (1973, 1979).

T. tephroleucus (Fr.) Donk coll.

Betula 46\%, Picea abies 38\%, Alnus 13\%, Tilia cordata $3 \%$. The taxonomy of this collective species has not yet been satisfactorily worked out. At least two elements seem to be included: the specimens on conifers mostly have a rough upper surface, while those on deciduous trees are often smooth and covered by a translucent pellicle. Crossing studies are necessary to settle this question.

T. undosus (Peck) Murr.

Picea abies ( 3 finds). New to Finland. This species is characterized by an elastic pileus with an undulating margin, fairly large pores, narrow spores and very thickwalled generative hyphae. It often grows on moss-covered, strongly decayed trunks.

\section{Discussion}

\section{Molikko}

Although the study area in Molikko was small compared with the others, surprisingly many polypore species were collected there. The difference between the numbers of species found in Molikko (57) and Vesijako (69) is very small, considering the bigger size and the virgin character of the latter area. With its luxuriant grass-herb forest, harbouring many demanding vascular plants and southern hardwood species, the area in Molikko contains sites where a rich variety of polypores can be expected. The rarity or absence of coniferdwelling polypore species (due to the rarity or absence 
of conifers) is well compensated by the presence of other, often rare, species: Only in Molikko did we find Antrodia plicata, Junghuhnia nitida, Meruliopsis taxicola, Oxyporus populinus, Polyporus umbellatus, Poria romellii, and the following species reached their maximal abundance there: Antrodia salicina, Ceriporia viridans, Ganoderma applanatum, Gloeoporus dichrous, Phellinus conchatus, Trametes zonatella and Tyromyces subcaesius 'f. minor'.

Datronia mollis, Phellinus punctatus and Schizopora paradoxa occur especially regularly in the dense, humid brook-side grass-herb forest, and in fact are characteristic of the polypore communities there.

This type of forest is that most influenced by man, and one can imagine how rich in species it would be, if it were larger in size and preserved in its original virgin state.

\section{Vaarunvuori}

The hilly topography and the variation from hardwood grass-herb forest to pure pine and spruce stands place this area somewhere in between the extremes of Molikko and Vesijako. The humid deciduous forest resembles that in Molikko, and the interesting records from there are Ceriporia reticulata and $C$. viridans.

The dry and poor pine forest characterized by an undergrowth of Calluna vulgaris (CT forest site type) bears a close resemblance to pine forest of Edessalo. Rare species found there were Anomoporia bombycina, A. myceliosa, Antrodia salicina, Parmastomyces kravtzevianus, Strangulidium rennyi and Tyromyces leucomallellus. Although harbouring rather few polypore species, these dry forests sometimes reward a keen collector with a rarity.

Although the vegetation in the Vaarunvuori area is very diverse, the number of fungi collected was low in this study. The difference from the other areas is not great, but this area might have been expected to have the highest amount of polypore species: it embraces forest sites that are both coniferous and deciduous, man-influenced and strictly protected, humid and dry. Perhaps the areas representing these different elements are too small to harbour stable stands of demanding species.

\section{Edessalo}

Being the largest of the study areas, Edessalo, too, comprises fairly varied vegetation types. The number of species collected (70) clearly indicates that this nature reserve is good from the mycological point of view.

The dry pine heaths close to the lake shores are rather poor in polypores. In all about 40 species were collected in this forest type, the characteristic species being Antrodia sinuosa, Gloeophyllum sepiarium, Junghuhnia luteoalba, Pycnoporus cinnabarinus,
Strangulidium sericeomolle, Trametes hirsuta, T. velutina and Trichaptum fuscoviolaceum; the rare species Hapalopilus salmonicolor and Parmastomyces kravtzevianus were also found there, the biotope being especially typical of $P$. kravtzevianus.

The mixed spruce forests in the interior of the island were richer in species: 68 polypores were found there. These were mostly common species, but scattered deciduous trees, e.g., Tilia cordata in some luxuriant depressions and Salix caprea in bog-side forest raised the number of species. This was the only study area with the rare Haploporus odorus, and it also yielded the only Finnish record of Onnia triquetra.

Though old, these protected forests have not yet reached the climax stage, and their fungal flora may still be expected to increase.

\section{Vesijako}

The greater part of the Vesijako National Park is covered with dense spruce forest interspersed with birch, pine and aspen. It fully represents the climax stage, containing abundant decaying wood. It was the best studied of the four areas, being visited from July to late September. It is, therefore, not surprising that the number of polypore species found was high (69). The conifer-inhabiting species formed the main part of the collections, and the only species not represented were those preferring man-made biotopes, such as Gloeophyllum sepiarium and Trichaptum fuscoviolaceum.

The most interesting species in Vesijako were those classified by Eriksson and Strid (1969) as the 'taiga species': Amylocystis lapponica, Fomitopsis rosea, Incrustoporia stellae, I. tschulymica, Leptoporus mollis and Phellinus ferrugineofuscus. Often some of these occur together on the same trees. The type of fallen spruce trunks found here is a familiar sight in northern Finland. The trees have generally first been infected by Fomitopsis pinicola, then rapidly killed. After falling they mostly remained corticated and supported above the ground by undecayed branches.

The fallen spruce trees killed by Heterobasidion annosum mostly have a different saprophyte community. They are poorer in species, usually bearing only the fruit bodies of $H$. annosum on the underside and Trichaptum abietinum in the crown. This may be partly due to the different microclimate in open areas created in the forest by the infections of $H$. annosum.

The occurrence of many 'northern' species in Vesijako shows that their distribution is delimited not only by the climate, but also by the occurrence of favourable habitats.

\section{General}

In this study altogether 97 species were detected. This number is high compared with the results of some other 
studies: Koskinen's (1955) list from the same area contains ca. 65 species, and these include some evident misidentifications (e.g., Trametes stereoides, T. subrosea) and double listings (Poria sinuosa and P. vaporaria). From the very different area of Aland (Ahvenanmaa) Laine (1967) reported 70 species. In northern Finland Eriksson and Strid (1969) found ca. 70 polypore species, and Norokorpi (1979) isolated 11 species from living spruce trees. In the Muddus National Park in the adjacent part of Sweden, Eriksson (1958) found 62 polypore species, and Strid (1975) reported 74 species from Central Sweden. The latter study, however, was restricted to alder forests, which limited the number of species.

The species listed from the present region by Koskinen (1955) but not found in this study were Antrodia heteromorpha, Bjerkandera fumosa (questionable), Phaeolus schweinitzii, Polyporus squamosus and Trametes versicolor (questionable). Of these, A. heteromorpha and $P$. schweinitzii could have been found in this study as well; the other species are best represented in parks and other man-influenced habitats.

An interesting problem touched on in this study is the true character of the so-called northern species, or 'taiga species'. Their occurrence, and even abundance, especially in Vesijako, indicated that the situation may be more complicated than was first believed. The distributions of these species do show concentration in the north-east, but the occurrence of Amylocystis lapponica and Incrustoporia tschulymica, for instance, in Central Europe (where they are not limited to the oroboreal zone on the mountains) indicates that their range could extend much farther southwards. It is prevented from doing so nowadays by the almost total disappearance of virgin lowland coniferous forests, which are the principal biotopes of these species. Of course there are also truly northern-continental species, but they are really few. A species of Daedaleopsis (Lenzites septentrionalis Karst.) and Trichaptum laricinum might be the best examples among the polypores, but they were not found in this study in southern Central Finland.

Acknowledgements. Our work was supported by a grant from the Academy of Finland.

The English of this paper was revised by Mrs Anna A. Damström, M.A.

\section{References}

Ahti, T., Hämet-Ahti, L. \& Jalas, J. 1968: Vegetation zones and their sections in northwestern Europe. - Ann. Bot. Fennici 5: 169-211.

Bondarcev, A. 1953: Trutovye griby evropejskoj časti SSSR i Kavkaza. - 1106 pp. Moskva.
Cajander, R. 1926: The theory of forest types. - Acta Forest. Fennica 29(3): 1-108.

Darimont, F. 1973: Recherches mycosociologiques dans les forêts de Haute Belgique 1. - Mem. Inst. Royal Sci. Nat. Belgique 170: 1 - 220 .

David, A. 1980: Etude du genre Tyromyces sensu lato: repartition dans les genres Leptoporus, Spongiporus et Tyromyces sensu stricto. - Bull. Mensuel Soc. Linn. Lyon 49: 6- 56.

Domański, S., Orłoś, H. \& Skirgieło, A. 1973: Fungi: Polyporaceae 2, Mucronoporaceae 2, Ganodermataceae, Bondarzewiaceae, Boletopsidaceae and Fistulinaceae. -332 pp. Warsaw.

Donk, M. 1974: Check list of European polypores. - 469 pp. Amsterdam.

Eriksson, J. 1958: Studies in the Heterobasidiomycetes Aphyllophorales of Muddus National Park in North Sweden. - Symb. Bot. Upsal. 16(1): 1-172.

Eriksson, J. \& Strid, A. 1969: Studies in the Aphyllophorales (Basidiomycetes) of northern Finland. - Ann. Univ. Turku (A II) 40 (Rep. Kevo Subarctic Sta. 4): 112-158.

Hallaksela, A-M. 1977: Kuusen kantojen mikrobilajisto. Microbial flora isolated from Norway spruce stumps. - Acta Forest. Fennica 158: 1-50.

Heikinheimo, O. \& Raatikainen, M. 1971: Paikan ilmoittaminen Suomesta talletetuissa biologisissa aineistoissa. The recording of localities of biological finds in Finland. - Ann. Ent. Fennici 37(1a): 1-27.

Hämet-Ahti, L., Jalas, J. \& Ulvinen, T. 1980: Suomen alkuperäiset ja vakiintuneet putkilokasvit. - Helsingin Yliop. Kasvit. Lait. Monist. 61: 1-111.

Jahn, H. 1963: Mitteleuropäische Porlinge (Polyporaceae s.lato) und ihr Vorkommen in Westfalen. - Westfälische Pilzbriefe 4: $1-143$.

- 1973: Einige in West-Deutschland (BRD) neue, seltene oder weniger bekannte Porlinge (Polyporaceae s.lato). Westfälische Pilzbriefe 9: $81-120$.

- 1978: Die Gattung Onnia P. Karst., Filzporlinge. Westfälische Pilzbriefe 11: 79-93. 1979: Pilze die an Holz wachsen. - 268 pp. Herford.

Kallio, P. 1963: Zur Verbreitung einiger in Finnland südlichen Pilze, besonders in der südwestlichen Eichenzone. - Karstenia 6-7: 35-76.

Kallio, P. \& Kankainen, E. 1966: Additions to the mycoflora of northernmost Finnish Lapland. - Ann. Univ. Turku (A II) 36 (Rep. Kevo Subarctic Sta. 3): 177-210.

Kallio, T. \& Norokorpi, Y. 1972: Kuusikon tyvilahoisuus. Summary: Butt rot in a spruce stand. - Silva Fennica 6: $39-51$.

Kallio, T. \& Tamminen, P. 1974: Decay of spruce (Picea abies (L.) Karst.) in the Åland Islands. - Acta Forest. Fennica 138: 1-42.

Karsten, P. 1859: Sydvestra Finlands polyporeer. - 47 pp. Helsingfors.

Koponen, T., Isoviita, P. \& Lammes, T. 1977: The bryophytes of Finland: An annotated checklist. - Flora Fennica 6: $1-77$.

Koskinen, A. 1955: Úber die Kryptogamen der Bäume, besonders die Flechten, im Gewässergebiet des Päijänne sowie an den Flüssen Kalajoki, Lestijoki und Pyhäjoki. -176 pp. Helsinki.

Kujala, V. 1979: Suomen metsätyypit. - Comm. Inst. Forest. Fenniae 92(8): 1-45.

Laine, L. 1976: Notes on the polypores (Polyporaceae) of Ahvenanmaa. - Karstenia 6-7: 14-20.

Linkola, K. 1917: Kasvistollinen retki Korpilahden Vaarunvuorelle ja sen jalavalehtoon. - Medd. Soc. F. Fl. Fennica 43: $144-155$.

Lowe, J. 1975: Polyporaceae of North America. The genus Tyromyces. - Mycotaxon 2: 1-82. 
Niemelä, T. 1971: On Fennoscandian polypores 1. Haploporus odorus (Sommerf.) Bond. \& Sing. - Ann. Bot. Fennici 8: $237-244$.

- 1972: On Fennoscandian polypores 2. Phellinus laevigatus (Fr.) Bourd. \& Galz. and P. lundellii Niemelä, n.sp. - Ann. Bot. Fennici 9: 41 - 59.

- 1974: On Fennoscandian polypores 3. Phellinus tremulae (Bond.) Bond.\& Borisov. - Ann. Bot. Fennici 11: $202-215$.

- 1975: On Fennoscandian polypores 4. Phellinus igniarius, $\mathrm{P}$. nigricans and $\mathrm{P}$. populicola, n.sp. - Ann. Bot. Fennici 12: $93-122$.

- 1976: Käävät - Polyporaceae s.lat. In: Ulvinen, T. (ed.), Suursieniopas. - Pp. 214-239. Helsinki.

- 1978a: The occurrence of some rare pore fungi in Finland. - Ann. Bot. Fennici 15: 1-6.

- 1978b: On Fennoscandian polypores 6. Antrodia plicata n.sp. - Karstenia 18: 43-48.

- 1980: Lahottajasienten yhteispeliä. - Sienilehti 32: 3-5.

- 1981: Polypores rare in or new to Finland. - Karstenia 21: $15-20$.

Norokorpi, Y. 1979: Old Norway spruce stands, amount of decay and decay-causing microbes in northern Finland. - Comm. Inst. Forest. Fenniae 97(6): 1 - 77.

Overholts, L. 1953: The Polyporaceae of the United States, Alaska, and Canada. - 456 pp. Ann Arbor.

Raatikainen, M., Saari, V., Kankaala, P., Karila, V., Kovanen, J. \& Pulkkinen, E. 1975: Korospohjan pumppuvoimalaitosalueen kasvisto ja eläimistö. - Jyväskylän Yliop. Biol. Lait. Tied. 2: 1-45.

Romell, L. 1911: Hymenomycetes of Lappland. - Ark. Bot. 11(3): 1-35.

Ryvarden, L. 1968: Flora over kjuker. - 96 pp. Drammen.
Ryvarden, L. 1971: Studies in the Aphyllophorales of Finnmark, northern Norway. - Rep. Kevo Subarct. Res. Sta. 8: $148-154$.

- 1976: The Polyporaceae of North Europe 1. Albatrellus to Incrustoporia. - $214 \mathrm{pp}$. Oslo.

- 1978: The Polyporaceae of North Europe 2. Inonotus to Tyromyces. - Pp. 219-507. Oslo.

Ryvarden, L. \& Johansen, I. 1980: A preliminary polypore flora of East Africa. - 636 pp. Oslo.

Saari, V. \& Ohenoja, E. 1976: Korpilahden Vaarunvuorten suursienistä. - Jyväskylän Yliop. Biol. Lait. Tied. 5: $1-15$.

von Schulmann, O. 1955: Pilzstudien in Finnland. - Karstenia 3: $17-68$.

- 1960: Zur Kenntnis der Basidiomyceten Finnlands. - Karstenia 5: 5- 99.

- 1963: Zur Kenntnis der Basidiomyzeten Finnlands. - Karstenia 6-7: 5-34.

Stenlid, G. 1947: Några anteckningar om Ålands svampflora. - Mem. Soc. F. Fl. Fennica 23: 82-90.

Strid, Å. 1975: Wood-inhabiting fungi of alder forests in North-Central Scandinavia 1. Aphyllophorales (Basidiomycetes). Taxonomy, ecology and distribution. Wahlenbergia 1: $1-237$.

Šubin, V. \& Krutov, V. 1979: Griby Karelii i Murmanskoj oblasti. - 104 pp. Leningrad.

Thesleff, A. 1919: Studier öfver basidsvampfloran i sydöstra Finland. - Bidr. Känn. Finlands Natur Folk 79(1): $1-140$.

Ulvinen, T., Ohenoja, E., Ahti, T. \& Alanko, P. 1981: A check-list of the fungi (incl. lichens) of the Koillismaa (Kuusamo) biological province, N.E. Finland. - Oulanka Reports 2: $1-64$.

Accepted for publication

on February 16, 1981 